\title{
Analiza emocija u iskazima preživjelih iz sustava logora Gospić-Jadovno-Pag u ljeto 1941. godine
}

\author{
IGOR DRVENDŽIJA, VINKO DRAČA
}

Filozofski fakultet, Sveučilište u Zagrebu

\begin{abstract}
Sažetak
U ovom radu autori istražuju emocije preživjelih logoraša iz sustava logora Gospić-Jadovno-Pag u kojem su u ljeto 1941. ubijani ljudi srpskog i židovskog etniciteta te komunisti i ostali politički protivnici ustaškog režima. Pristup proučavanja emocija bazira se na svjedočanstvima koja je objavio povjesničar Đuro Zatezalo. U radu se prvo govori o analizi emocija u historiji s naročitim osvrtom na svjedočanstva preživjelih kao poseban i izuzetno važan izvor u studijama Holokausta i genocida. Autori također problematiziraju intenciju zapisivača, sjećanje i emocije kao aspekte koje povjesničar koji analizira svjedočanstva mora imati na umu. Daje se i opis djelovanja rasnih zakona Nezavisne Države Hrvatske i logora smrti Gospić-Jadovno-Pag, nakon čega se sustavno analiziraju emotivi izneseni u svjedočanstvima. Pritom se fokus istraživanja usmjerava na emocije straha, strepnje, nade i radosti. Također se problematizira odnos sjećanja i emocija te način na koji protok vremena može izmijeniti intenzitet i sadržaj emocije, što može biti vrijedan metodološki prilog proučavateljima povijesti genocida i oralne povijesti uopće.

Ključne riječi: Nezavisna Država Hrvatska, Jadovno, stradanja civila u Drugom svjetskom ratu, emocije, svjedočanstva
\end{abstract}

\section{Uvod}

Bez obzira na to koju epistemološku i istraživačku poziciju zauzela, moderna proučavanja genocida ne mogu izbjeći ozbiljno bavljenje pojmom traume. Užasi Holokausta, masovnog pokolja koji se dogodio u samom srcu Europe transformirali su naš pogled na prošlost, učinili nasilje vidljivim te nagnali povjesničare i ostale društvene i humanističke znanstvenike da se bave njihovim posljedicama na pojedince i zajednice. S druge strane, okret prema traumi vjerojatno se ne bi dogodio da se do druge polovice dvadesetog stoljeća nije temeljito izmijenio naš pogled na 
emocije. Joanna Bourke navodi kako je u vremenu od 1939. godine do kraja šezdesetih godina prošlog stoljeća diskurs o strahu bio radikalno transformiran popularizacijom psihologijskih spoznaja. Dok se u prvoj polovici stoljeća strah smatrao jednostavnim evolucijskim instinktom, ratni memoari nastali poslije Drugog svjetskog rata govore o strahu na mnogo kompleksniji način. Informirani psihoanalitičkim teorijama, često povezuju strah sa seksualnim te, sve više, s dugotrajnijim osjećajima strepnje (Bourke, 2003: 120-121). Od psihoanalitičkog diskursa o strepnji do diskursa traume kao iskustva koje transformira ličnost ostaje malen korak. Devetnaestostoljetnu traumu zamišljenu kao fiziološko oštećenje živaca uslijed željezničke nesreće (railway spine) ili udara granate (shellshock) zamijenila je usustavljena psihijatrijska dijagnoza posttraumatskog stresnog poremećaja, stanja uzrokovanog isključivo izlaganjem traumatičnom događaju (American Psychiatric Association, 2013: 271). Historijski rad o stradanjima, nasilju i strahu, posebno onaj koji se zasniva na svjedočanstvima žrtava i svjedoka, čini ozbiljnu metodološku pogrešku ako iz svoje analize izostavlja emocije i traumu. Prema tome, ni povjesničari, kada se govori o Holokaustu na području Nezavisne Države Hrvatske, ne mogu ne spomenuti dugoročne i sveobuhvatne posljedice traume genocida i masovnih pokolja na preživjele i na društvo u cjelini. Upravo iz tog razloga u ovom ćemo se radu baviti ustaškim zločinima u sustavu logora Gospić-Jadovno-Pag. Pored samih zločina analizirat ćemo i emocije preživjelih. Svrha je ovog rada pokazati kako svjedočanstva, osim svoje faktualne vrijednosti, mogu poslužiti kao uvid u emotivni svijet ljudi koji su preživjeli logore smrti, ali su svjedočili svirepim zločinima nad drugima. Također, analiza svjedočanstava pokazat će da ponovno proživljavanje emocija ima značajnu ulogu za formiranje i artikulaciju samih svjedočanstava koja postaju neophodan dio historijskog i šireg društvenog narativa o zločinu.

\section{Perspektive u historijskom istraživanju emocija i istraživanje emocija u svjedočanstvima o Jadovnu}

Povijesno istraživanje emocija, usprkos tradiciji koju vuče od Luciena Fevbrea i Jeana Delumeaua, još uvijek je novo područje u proučavanju prošlosti. Glavni je razlog tome činjenica da su se emocije u prijašnjim radovima uzimale kao nepromjenjive forme određene ljudskom prirodom i odvojene od konkretnih povijesnih iskustava. Takav pogled na emocije možemo naći kod Delumeaua koji strah i strepnju, usprkos detaljnim definicijama u svom kapitalnom djelu Strah na Zapadu, uzima kao prirodne i jasno odvojene kategorije koje se, doduše, mogu prožimati i među kojima su mogući prijelazi, ali koje ne ovise o konkretnim povijesnim prilikama. Delumeau ih objašnjava psihoanalitičkim kategorijama koje ne propituje kao konstrukte podložne dijakronijskom proučavanju, već kao unutarnja svojstva ličnosti koja proizlaze iz njene zadane strukture. Umjesto kvalitativnog proučavanja emo- 
cija, Delumeau će se radije baviti njihovim intenzitetom i prisutnošću ili odsutnošću; svoju će studiju započeti lakonskim zaključkom da su nestanak vjerovanja u magiju i uspon znanstvene misli u osamnaestom stoljeću doveli do smanjenja straha u posljednja dva stoljeća (Delimo, 2003: I). Ta se tvrdnja pokazuje sve problematičnijom što više proučavamo čovjekov emotivni svijet. Novija istraživanja straha i anksioznosti, poput onih američkog povjesničara emocija Petera Stearnsa, ukazuju na stalnu promjenu i prožimanje navedenih emocija. Također, navedene je emocije teško proučavati izvan njihovog društvenog konteksta, što uključuje i same stavove ljudi prema njima.

Univerzalistički pristup emocijama nije isključivo problem Delumeaua. Američki psiholog i antropolog Paul Ekman posvetio je život pronalaženju osnovnih emocija na temelju proučavanja facijalnih ekspresija. Ekman je kao osnovne emocije identificirao sreću, bijes, gađenje, strah, tugu i iznenađenje (na engleskom: happiness, anger, disgust, fear, sadness and surprise). Pri opisivanju emocija Ekman nije obraćao pažnju na razliku u semantičkim opsezima riječi kojima se u engleskom te emocije nazivaju, iako su one opterećene kulturnim i društvenim teretom simboličkog, te je smatrao sasvim nevažnim kako se emocije nazivaju jer se one mogu pokazati izrazima lica koje je nemoguće prikriti (Plamper, 2015: 149). Univerzalističke perspektive bile su kroz čitavo devetnaesto i dvadeseto stoljeće dominantan pogled na emocije u psihologiji, psihijatriji i psihoanalizi. Razumljivo je da su i povjesničari koji su se odlučili posvetiti proučavanju emocije svoje znanje o ljudskoj psihi dobivali preko spoznaja navedenih znanosti, što je otežalo bilo kakvo proučavanje emocija kao društveno i historijski promjenjivih fenomena.

Konstruktivistički pristupi proučavanju emocija razvijali su se primarno unutar kulturne antropologije i u drugoj polovici dvadesetog stoljeća. Glavne teorijske postavke konstruktivizma objašnjavaju emocije kao partikularne performativne akte, kojima se u određenom kulturnom kontekstu mogu priopćiti kompleksni kognitivni procesi koje pojedinac doživljava. Prema tome, načini izražavanja emocija, njihovi opisi i njihovi objekti se mijenjaju. U primjeru koji iznosi Joanna Bourke strah od toga da bi čovjek mogao biti živ pokopan naglo se proširio u građanskim krugovima druge polovice devetnaestog stoljeća pod utjecajem sekularizacije i medikalizacije samog iskustva umiranja, koje sve manje biva intimnim i spiritualnim procesom (Bourke, 2006: 34). Taj objekt straha i manifestacije njegovog iskazivanja (zvonca i kasnije telefoni ugrađeni u grobnice, običaj da se srce nakon smrti probode skalpelom kako bi se osiguralo da je osoba doista mrtva) nova su pojava koja predstavlja jasan diskontinuitet $u$ odnosu na prethodne strahove vezane uz smrt i umiranje. Ako emociju definiramo kao kognitivni subjektno-objektni odnos, pojava novog objekta straha kvalitativno mijenja i samo iskustvo straha kao jednog od elemenata emocionalne svakodnevice. 
Povjesničar emocija William Reddy, koji je proučavao emotivne tvorbe u francuskom građanskom društvu od sredine osamnaestog do sredine devetnaestog stoljeća, definira emociju kao "aktivaciju misaonog materijala koja je potaknuta određenim usmjerenim djelovanjem i koja premašuje mogućnost prevodilačkog djelovanja naše pažnje u kratkom vremenskom obzoru" (Reddy, 2001: 144). Ta komplicirana definicija zapravo znači da se emocija sastoji od niza povezanih kognitivnih tvorbi koje se manifestiraju u roku prekratkom da bi ga naša svijest mogla procesuirati kao zasebne misli ili impulse, te se najčešće izražavaju kao nesvjesna fiziološka reakcija i/ili prolazno mentalno stanje. Prvi dio definicije povrh toga govori da one najčešće imaju usmjereno djelovanje, što znači određen subjektno-objektni odnos: cilj je romantične ljubavi tako priuštiti sreću voljenoj osobi i što češće biti u njenoj fizičkoj blizini (ibid.: 107), a cilj je straha postaviti što veću razdaljinu ili fizičku barijeru između sebe i objekta straha. Emocije će se najčešće iskazivati nekim komunikacijskim činom koji indicira njihovu prisutnost i njihov mogući objekt te koji njihovu prisutnost komunicira okolini. Taj komunikacijski čin također utječe na kognitivne tvorbe koje čine samu emociju. Ako, na primjer, stočar iz Like u vrijeme Drugog svjetskog rata čuje pucnjavu u daljini, to ga može natjerati da se nesvjesno trzne - srce mu počinje ubrzano lupati i njegovi pokreti počinju odavati želju da se što više odmakne od percipiranog mjesta s kojeg pucnjava odlazi. U trenutku kad si stočar prevede svoje misaone tvorbe kao emociju straha, on bi ih sam sebi mogao artikulirati otprilike u ovom obliku:

Budući da je rat, pucnjava može značiti prisutnost vojnika. Moje iskustvo i kulturno sjećanje mi govori da bi vojska mogla nauditi meni i bližnjima: mogli bi mi oduzeti stoku i tako me izložiti gladi i neimaštini, mogli bi me prisilno unovačiti, odvesti u zarobljeništvo ili ubiti. Zbog toga se bojim vojske.

U trenutku kad subjekt artikulira emociju i njen objekt, ujedno ju stavlja u vlastiti kulturni okvir, koji često predviđa valenciju (je li emocija pozitivna ili negativna, poželjna ili nepoželjna) i poželjno djelovanje (u slučaju uplašenog stočara ono bi moglo biti "otići ću u šumu dok se vojnici ne udalje. Ako budem imao vremena, povest ću i stoku sa sobom”). Samim time misaoni sadržaj emocije više nije isti nakon što se ona artikulira - više nije visceralan i instinktivan, već povezan $\mathrm{s}$ konkretnim iskustvenim sadržajem. Takve govorne činove koji istovremeno opisuju i mijenjaju misaoni sadržaj emocija, te su prema tome istovremeno deskriptivni i performativni, Reddy je nazvao emotivima (ibid.: 144). Skup emocija i službenih rituala, praksi i emotiva kojima se iste izražavaju i potvrđuju čine emotivni režim.

Boljem razumijevanju kulturnog i društvenog značenja emocija može pridonijeti i podjela na hiperkognizirane i hipokognizirane emocije koju je uveo pionir antropologije emocija Robert Levy. Po Levyju, koji je svoja istraživanja provodio 
na Tahitiju, nemaju sve emocije jednak društveni značaj - nekima se pridaje veća težina, drugima manja. One emocije kojima se unutar određene društvene skupine pridaje velika važnost Levy je nazvao hiperkogniziranima, a one koje su doživljene, ali manje važne - hipokogniziranima (Plamper, 2015: 95-96). Važnost je takve podjele emocija za historijska istraživanja u činjenici da će hiperkognizirane emocije biti znatno prisutnije u izvorima od hipokogniziranih. Također, upravo će se na temelju hiperkogniziranih emocija moći najbolje opisati pojedini elementi emotivnog režima jer će rituali kojima se emocije izražavaju biti normirani na način da pridaju određeno društveno značenje hiperkogniziranim emocijama. Hipokognizirane emocije, s druge strane, neće biti obilježene osobitom težinom društvenog značenja i bit će ih teže detektirati u izvorima.

U historijskom proučavanju emocija nužan je pristup koji je jedan od prvih povjesničara emocija Peter Stearns nazvao emocionološkim (eng. emotionological approach). Emocionološki pristup možemo definirati kao pokušaj određivanja kako pojedine kulture klasificiraju i prepoznaju emocije. Taj koncept nam omogućuje da napravimo jasniju distinkciju između iskazanih vrijednosti i subjektivnog iskustva tako što ćemo vidjeti koji je bio društveni značaj pojedinih emocija, kojim su riječima opisivane i koji su emotivi činili pojedini kulturno uvjetovani emotivni režim (Bourke, 2003: 117).

Budući da se ovaj rad bavi proučavanjem emocija preživjelih žrtava u sustavu logora smrti Gospić-Jadovno-Pag, prvi njegov dio bit će posvećen historijatu samog logora, dok će se u drugom dijelu analizirati svjedočanstva preživjelih i počinitelja. Radi se o izrazito traumatičnim događajima i zbog toga će naglasak biti na onim emocijama koje ljudima pomažu procesuirati iskustvo izloženosti posvemašnjem fizičkom uništenju i dehumanizaciji. Povijest genocida i Holokausta obiluje analizama specifičnog emotivnog sadržaja narativa preživjelih. Osobita pažnja bit će zbog toga posvećena onim elementima traumatičnog iskustva koji oblikuju naknadno govorenje o emocijama.

Emocije će se u ovom radu promatrati pomoću emocionološke analize svjedočanstava vezanih uz Jadovno koje je između 1960. i 1994. godine prikupio i objavio povjesničar Đuro Zatezalo, kao i nekoliko svjedočanstava koja su zapisana još ranije, tijekom ratnih i poslijeratnih godina, a koja je Zatezalo uključio u svoju knjigu. Rad će se dotaći i svjedočanstava koja je Ante Zemljar objavio u svojoj knjizi $\mathrm{Ha}$ ron $i$ sudbine vezanih uz logore smrti Slana i Metajna na otoku Pagu, koji su također dio gospićkog sustava logora. U navedenim svjedočanstvima autori će analizirati emotivni doživljaj traumatičnih događaja koji su se odvili u ljeto 1941. te kako su ih žrtve procesuirale u okviru svog emotivnog režima. Pritom valja naročito imati na umu činjenicu da prikupljena svjedočanstva često ne bilježe neverbalne reakcije preživjelih. Budući da su autori ovog rada analizirali svjedočanstva na temelju 
zapisa objavljenih u knjigama, neki emotivni sadržaji koji su bili dostupni samim ispitivačima, poput promatranja izraza lica, govora tijela ili intonacije glasa, nisu uključeni u analizu. Metodološki problem navedenih svjedočanstava dijelom je i u tome što ni Zemljar ni Zatezalo nisu bili zainteresirani za analizu emocija, već su bili motivirani objelodanjivanjem činjenica povezanih s genocidom koji su provele vlasti Nezavisne Države Hrvatske. No, iako intencija pri bilježenju svjedočanstava nije bila proučavanje emocija, svjedoci često spontano govore o svojim emocijama. Upravo će ti spontani iskazi emocija biti fokusom analize u ovom radu.

\section{Svjedočanstva žrtava, sjećanje, trauma i emocije}

Budući da je većina svjedoka o vlastitim iskustvima govorila nakon višegodišnjeg vremenskog odmaka, emocije koje se javljaju u iskazima često su naknadno procesuirane. Prema tome, osobitu pažnju trebamo posvetiti trima diskurzivnim odnosima koji su važni u analizi svjedočanstava. Prvi je odnos svjedoka s onima koje svjedok percipira kao recipijente svog iskaza. Naime, iako su svjedočanstva u trenutku njihovog prikupljanja imala svrhu "saznavanja istine", sam traumatični karakter događaja o kojima se u njima govori čini od njih i duboko osoban i intiman iskaz. Svjedočanstvo se, prema svojoj svrsi, nalazi negdje između javnog i privatnog - ono govori o individualnom stradanju, no kontekst genocida u kojem se to individualno stradanje odvija duboko je politiziran. Dapače, možemo reći da sam čin etnički motiviranog nasilja direktno politizira svakodnevicu aktera, pa samim time i njihova osobna prisjećanja postaju politički čin. Svjedočanstvo je također određeno intencijom onoga koji ga prikuplja, što se naročito vidi u svjedočanstvima hrvatskih Srba koja su prikupljana za vrijeme rastućih etničkih trvenja u posljednjim godinama Jugoslavije. Đuro Zatezalo je pri bilježenju tih svjedočanstava stavljao naročit naglasak na poruke preživjelih koji su opominjali na fatalne posljedice koje bi ponovno razbuktavanje etničke mržnje moglo imati za Srbe i Hrvate. Proučavanje iskaza preživjelih kao specifičnog narativnog žanra jedan je od gorućih problema u studijama genocida. U dijalogu skupine znanstvenika iz različitih područja koji je 2014. objavljen u časopisu "Dapim: Studies on the Holocaust" psiholog Henry Greenspan istakao je da je svjedočanstvo uvijek određeno svojim institucionalnim kontekstom, ali i da se sami svjedoci često čak i eksplicitno opiru tome da ih se shvaća kao one koji naprosto "dokumentiraju” prošli događaj, već žele prenijeti određenu poruku i ispreplesti svjedočenje o prošlosti s osobnim refleksijama. Mnogi čak imaju vlastitu "poruku" koju svojim svjedočanstvom žele poslati društvu u cjelini (Greenspan i dr., 2014: 194). Primjeri isticanja osobnih refleksija vidljivi su u brojnim svjedočanstvima o Jadovnu. Branko Cetina, preživjeli iz Jadovna, svoje je svjedočanstvo koje je iznio Đuri Zatezalu završio komentarom koji bi mogao odražavati i njegovu strepnju glede postojeće političke situacije: 
Danas, ove 1988. godine, moj doktore Đuro, plašim se naše dalje sudbine... (Zatezalo, 2005: 270)

Mnogi svjedoci čija je iskustva Zatezalo zabilježio upuštaju se u komentare trenutne političke situacije. Stevo Brakus, svjedok pokolja koji su ustaše 16. lipnja 1944. počinili u Brakusovoj Dragi kraj Otočca, tako je 1990. godine povezao svoje stradanje s tadašnjom političkom situacijom u Hrvatskoj:

Mislim da se opet sprema zlo. Čujem što se priča u narodu. Kažu da u Hrvatskoj mogu živjeti samo Hrvati. Ja sam malo vremena bio u Engleskoj pa sam vidio i čuo da tamo živi zajedno hiljadu nacija, a zakon je za sve isti što bi nam moglo biti putokaz kako naprijed. Ljudi koje srećem također su uplašeni. Samo mislim da se danas narod ne bi dao voditi kao ovce na klaonicu, kao mi nekad. Ipak, mladi nijesu upamtili rat, pa ko će ga znati kako bi se ponašali. (ibid.: 278)

Neki od Zatezalovih svjedoka koriste svoja svjedočanstva kako bi ukazali na vlastiti težak egzistencijalni položaj. Takav iskaz proizlazi iz njihovog shvaćanja svjedočanstva kao iskaza preko kojeg oni kao ljudi iz ruralnih sredina ulaze u interakciju s institucijama vlasti i širom javnosti. Kazivači tako odlučuju upotrijebiti interes istraživača za njihovu priču, a sam čin svjedočanstva percipiraju kao način da ukažu na vlastitu tešku situaciju. U razgovoru sa Sofijom Uzelac iz Brakusove Drage sam Zatezalo inicira razgovor o primanjima svoje kazivačice:

"Reci mi, teto Sofija, kakvu pomoć primate od države?"

"A šta me pitate? Za pobijenu djecu nikada nisam primala nikakvu pomoć, a tek od 1977. godine primam neku invalidninu mizeriju i čekam samo da umrem." (ibid.: 274)

Poruke kazivača ponekad pozivaju na izvršenje pravde nad zločincima koji su zbog propusta pravosudnog sustava ili policije prošli nekažnjeno ili izražavaju želju za dostojnom komemoracijom žrtava. Stevo Brakus tako izražava frustraciju zbog neobilježavanja mjesta stradanja svojih najmilijih, da bi kasnije prepričao susret $\mathrm{s}$ jednim od zločinaca, kao i izostanak reakcije policije:

Mjesto gdje su kosti naših najmilijih sahranjene ničim nije ni do današnjeg dana obilježeno. Mi preživjeli, kojih nas je ostalo malo, nemamo novaca, a naše države nije ni briga, pa se tako za mjesto naših mrtvih naprosto ne zna. Ustaše koje su počinile ovaj stravični zločin bile su uglavnom iz naših susjednih hrvatskih sela i mjesta. Tako sam jednoga od ustaša koji su nas ubijali samo zato što smo Srbi prepoznao poslije rata. Rodom je bio iz Kompolja, a zvao se Nikola. Poginuo je na traktoru 1989. Prijavio sam miliciji u Otočcu da je on bio u grupi ustaša koji su nas masakrirali i u kući zapalili, ali su mi oni rekli da o tome nikome ne govorim i da ne bi bilo dobro da se sad raspiruje nacionalna mržnja i tako je ostalo. A šta možemo, možda je to i bolje. (ibid.: 276) 
Drugi problem odnosi se na utjecaj traumatičnog iskustva na pamćenje određenog događaja. Traumatično iskustvo je u neku ruku ahistorično pošto djeluje disruptivno na narativ pojedinca o vlastitom životu i zadire u same osnove identiteta traumatizirane osobe. Također, traumatično iskustvo opire se klasičnim oblicima kauzalne racionalizacije te velikim dijelom ostaje neobjašnjivo. To osobito vrijedi za epizode izrazito intenzivnog etnički motiviranog nasilja kakvo je karakteriziralo fašistički režim NDH i za koje u individualnom ili povijesnom sjećanju žrtava nije bilo povijesnog presedana. Izraelski psihoanalitičar Dori Laub u svojim je intervjuima s preživjelim žrtvama Holokausta pokazao kako su sami kazivači bili zapanjeni količinom detalja kojih se sjećaju i koje mogu artikulirati. Prema Laubu, "masivna psihička trauma genocida rezultira ekstenzivnom fragmentacijom kod preživjelih - fragmentacijom percepcije, fragmentacijom osjećaja koherencije te fragmentacijom veza s obitelji i širom zajednicom". Čin svjedočenja omogućuje žrtvi da u interakciji s Drugim (slušateljem) re-eksternalizira i historizira događaj koji je rezultirao traumom (Laub, 2002: 63). Kako bi povratili fragmentirani osjećaj koherentnosti, svjedoci se utječu historizaciji sjećanja, odnosno uobličavanju istog u koherentni narativ koji de-fragmentira proživljeno iskustvo i ponovno uspostavlja vezu između individualnog iskustva, vremenskog toka i šireg društvenog konteksta. Takva historizacija traumatičnog sjećanja znači da žrtva na neki način mora ponovno proživjeti događaj. Bitan dio ponovnog proživljavanja traumatičnog iskustva jest uklapanje istog u određeni vremenski tok kako bi se traumi dao narativni okvir "historičnosti" i kako bi dobila određeni smisao u sklopu svjetonazora pojedinca (Greenspan i dr., 2014: 199). Upravo zbog toga neka svjedočanstva žele početak traumatičnih iskustava progona i zlodjela vezati uz specifični događaj ili datum koji za njih predstavlja točku diskontinuiteta, "trenutak kad je sve krenulo na zlo". Za đakona Vukašina Stjepanovića, svjedoka zločina u Gospiću, tako su prijelomne točke bile trenutak uspostave NDH koji svjedok smješta izrazito vremenski precizno ("Na veliki četvrtak, 10. aprila, u pet sati") i govor Mile Budaka koji je jedne nedjelje održao na skupštini u Gospiću, "pa je toga dana Srbima zabranjeno služiti službu" (Zatezalo, 2007: 79). Nevenka Glumičić Lastavica početke pokolja također povezuje s posjetom Mile Budaka Kosinju, koji se prema njenoj izjavi dogodio 26. srpnja 1941. (Zatezalo, 2005: 286). Takva svjedočanstva daju temporalni okvir traumatičnom događaju i zapravo usko povezuju početke zločina s prvim susretima koje su žrtve imale s predstavnicima fašističke ideologije, ljudima koje su smatrali nalogodavcima zločina. Oko tih specifičnih "prijelomnica" u individualnom narativu bit će organizirano svjedočanstvo - žrtve se najčešće precizno sjećaju tih trenutaka i do u detalje mogu opisati zbivanja neposredno poslije njih koja su historizirana tim specifičnim okvirom. I same emocije često će biti organizirane oko određenih prostora ili datuma, te će njihovo spominjanje unutar narativa rezul- 
tirati spontanim iskazima različitih, uglavnom intenzivnih emocija. Često se javlja i emotivni sadržaj pozitivne valencije kako bi se jače naglasio kontrast s kasnijim traumatičnim događajima. Svjedočanstvo Dušana Nikšića iz Donjeg Poloja, koji je svjedočio zločinima u Veljunu, tako počinje opisom svečane atmosfere Đurđevdana, jednog od bitnijih datuma u kalendaru pučkog pravoslavlja:

6. maj Đurđevdan, godina 1941. Osvanuo je lijep sunčan dan. Toga dana Srbi se svečanije odijevaju, idu jedni drugima na Krsnu slavu u goste, razgovaraju o uspjesima u obavljanju proljetne sjetve. Vesele se i raduju. Sve je razdragano i svečano. (ibid.: 14)

Atmosferu vedrog ljetnog dana i anticipaciju žetvenih svečanosti donosi i Nevenka Glumičić Lastavica:

... Bilo je to u srijedu, 6. augusta 1941. godine. Žito je već bilo dozrelo čekajući žetelice da ga uz pjesmu i tamburice počnu savijati u snopove. (ibid.: 286)

U nekim svjedočanstvima prijelomni datum biva određen kao simbolički početak traume i emotivi isključivo iskazuju emocije negativne valencije. Petar Pavlica iz Sela Ploča kraj Gračaca, koji je uspio pobjeći iz kamiona koji je prevozio Srbe iz njegovog sela prema logoru smrti Jadovno, smješta specifičan datum u središte traume koja mu je obilježila ostatak života:

Bilo je to 31. jula 1941. godine. To je dan koji mi se urezao u sjećanje, pa ga često i noću sanjam. Doživljavam osjećaj straha. (ibid.: 319)

Moramo biti svjesni karakteristike svjedočanstava da traumatični doživljaj smještaju u određene vremenske i prostorne okvire koji su jasno ograničeni i unutar kojih kazivač može s velikom preciznošću ponovno prizvati emocije. Te su emocije također najčešće usidrene oko specifičnih prostornih i vremenskih točaka, i kazivaču te točke pomažu pri uklapanju emocija u osobni narativ. U metodološkom smislu važno je da vremenske i prostorne točke, kojima se u svjedočanstvima daje specifičan značaj, ne pokušamo univerzalizirati. Njihov je značaj ukotvljen isključivo u osobnim iskustvima i one imaju svrhu defragmentacije narušenog osjećaja koherencije i davanja smisla događaju koji je bio duboko traumatičan. Budući da emocije vezane uz te uokvirujuće koordinate sjećanja mogu varirati - ponekad se pozitivno kognizirane emocije stavljaju u kontrast s kasnijim traumatičnim iskustvom, a u nekim se drugim svjedočanstvima naglašava intenzitet i trajnost negativno kogniziranih emocija - one nisu sadržaj kolektivne traume u arhetipskom smislu, već sustav emotivnih referenci u unutrašnjoj historiji pojedinca.

Treći odnos koji valja problematizirati odnos je svijesti, emocija i pamćenja u osobnim narativima. Činjenica da su svjedočanstva iznesena nakon što je od događaja prošao određeni, najčešće višegodišnji vremenski period čini ih formom 
prisjećanja i (re)konstrukcije događaja, što znači da emotivni sadržaj također biva (re)konstruiran i ponovno proživljen. Budući da se emocije sastoje od kompleksnih kognitivnih tvorbi, upitno je mogu li se rekonstruirati u potpunosti ili se prilikom svakog svjedočanstva radi o novoj emociji. Pritom interakciju emocija i pamćenja ne treba gledati kao proces koji se isključivo događa u svijesti pojedinca, već kao jedan od neuro-kognitivnih procesa koji oblikuju svijest pojedinca o vlastitom sebstvu i njegovoj interakciji s okolinom.

Neuroznanstvenik Antonio Damasio podijelio je sam proces osjećanja na tri stadija: stanje emocije, stanje osjećaja i stanje osvještavanja osjećaja, pri čemu se u prva dva stadija emocija može manifestirati nesvjesno, a tek u trećem stadiju postajemo svjesni emocije i osjeta koji emocija u nama izaziva (Damasio, 1999: 37). Za Damasijevo shvaćanje emocija ključna je upravo distinkcija između emocije kao skupa reakcija na podražaje koji se mogu opaziti izvana te osjećaja kao mentalnog iskustva emocije (ibid.: 42). U Damasijevoj podjeli emotivi bi imali dvojnu ulogu. Oni bi izražavali i opisivali emocije u određenoj socijalnoj interakciji, ali i pomogli osvještavanju vlastitog osjećaja. Samim time oni istovremeno opisuju dva nesvjesna procesa - reakciju na emociju i mentalno iskustvo iste. U slučaju svjedočanstava emocije i osjećaji u pojedinim trenucima postaju transtemporalni te se briše granica između prisjećanja nekadašnjih traumatičnih emocija i današnjih emocija. Početak već spomenutog svjedočanstva Petra Pavlice sadrži takav primjer:

Bilo je to 31. jula 1941. godine. To je dan koji mi se urezao u sjećanje, pa ga često i noću sanjam. Doživljavam osjećaj straha. Padam u agoniju kao da se i danas, poslije toliko vremena, nalazim u kamionu s ustašama. Osjećaj, ideš na klanicu kao stoka. (Zatezalo, 2005: 319)

Petar Pavlica povlači direktnu analogiju između osjećaja straha koji doživljava trenutno kada sanja ili reminiscira o traumatičnom odvođenju put Jadovna i osjećaja koji je doživio tada. Radi se zapravo o gustoj isprepletenosti traumatskog sjećanja i osjećaja koja u umu kazivača omogućava "prijelaz" između prošlog i sadašnjeg osjećaja. Pavlica na kraju potpuno osvješćuje svoj osjećaj napravivši analogiju s "odlaskom stoke u klanicu” kako bi osjećaju straha pridodao osjećaj bespomoćnosti i očaja te tako u okviru svjedočenja prizvao kompleksan skup emocija koje je doživljavao dok su ga prevozili u logor.

Sličan primjer ponovnog proživljavanja osjećaja nalazimo i u svjedočanstvu Jakova Balaža koji je preživio mučenje u logoru Slana, a čiji je iskaz zabilježio Ante Zemljar. U transkriptu magnetofonski snimljenog razgovora supruga Jakova Balaža, koja je prisustvovala davanju iskaza, u jednom trenutku intervenira i opominje Balaža da se previše uzbuđuje. On potvrđuje svoje stanje emotivne uzbuđenosti riječima: 
Pa jesam, ja sam drugu jučer rekao: kad govorim o logoru ja drhtim, ja se bacim u ono vrijeme, ja žmirim da ne bih vidio ovo, da se lakše unesem u ono vrijeme. (Zemljar, 1988: 86)

Tijekom bilježenja svjedočanstva Balaževo emotivno stanje postalo je vidljivo ljudima koji su bili prisutni u prostoriji. Sam Balaž potvrđuje svoju uzbuđenost i govori kako joj se prepušta, zatvorivši oči kako ne bi vidio trenutne podražaje i kako bi se posve unio u vlastita sjećanja. Također opisuje vlastitu fiziološku reakciju drhtanja, koja ukazuje na intenzitet emocije koju ponovno proživljava. Proces prisjećanja prisutan u iskazu Jakova Balaža istovremeno je duboko privatan i javan. Balaž se s jedne strane svjesno i intencionalno povlači u unutarnji svijet vlastitih uspomena. Tim povlačenjem on priziva traumatične slike iz sjećanja, a efekt tih slika postaje vidljiv preko njegovih fizioloških reakcija. Njegovim objašnjenjem fizioloških reakcija i slike i emocija postaju javno vidljive prodirući u interpersonalni komunikacijski proces davanja iskaza. Radi se o procesu "materijaliziranja" traume putem svjedočenja. Kad je afroamerička spisateljica Toni Morrison u romanu $B e$ loved opisala spomenuti proces rekonstrukcije pamćenja u interpersonalnom činu, dala mu je ime "rememory" (Rushdie, 1990: 304). Interpersonalni čin svjedočenja o stradanjima i zločinima ne pomaže samo individualnim osjećajima i reminiscencijama da premoste vremenski jaz između događaja i iskaza o događaju, već isto čini i s emocijama, pa čak i njihovim fiziološkim manifestacijama.

Te tri vrste interakcije bit će temelj analize emocija u iskazima preživjelih. Cilj analize bit će odrediti koje emocije preživjeli naglašavaju u svojim svjedočanstvima, koju ulogu kazivači daju emocijama u formiranju narativa o proživljenoj traumi i kakva je interakcija između samih emotiva i mentalnog ponovnog proživljavanja traumatičnog iskustva.

\section{Uspostava Nezavisne Države Hrvatske}

Nakon što je u proljeće 1941. godine za svoje potrebe pacificiralo Balkan, vodstvo sila Osovine na osvojenim je područjima htjelo uspostaviti režime koji će biti lojalni i kojima će moći lako upravljati ne bi li se nesmetano moglo posvetiti daljnjim ratnim osvajanjima. Za područje koje će sačinjavati Nezavisnu Državu Hrvatsku odlučili su se za ustaški pokret zbog sličnosti u ideologiji, ali i zbog spremnosti ustaškog vodstva na brojne ustupke (Krizman, 1978: 468-474).

Ustaški režim jako rano počinje propisivati rasne zakone kojima se Srbi, Židovi i Romi stavljaju van zakona. Dana 17. travnja 1941. stupila je na snagu Zakonska odredba za odbranu naroda $i$ države (NDH, 1941: 15), prema kojoj se kaznom smrti kažnjava bilo koja osoba koja učini djelo veleizdaje, čime se zapravo omogućavao progon raznih ljudi za koje se odredilo da rade protiv interesa države. Dva 
dana nakon toga proglašena je Zakonska odredba o nekretninama tzv. dobrovoljaca (ibid.: 21), čime je započet proces prisilnog sistematskog iseljavanja Srba iz NDH u Srbiju (Škiljan, 2014). Spomenutom zakonskom odredbom najprije se ciljalo na solunske dobrovoljce (poglavito u Slavoniji i Srijemu), da bi se kasnije prešlo na viđenije Srbe općenito u NDH, npr. trgovce, politički aktivne Srbe, pravnike, sveštenike, istaknute seljake i dr. Jedna od posljedica takvog pristupa je obezglavljivanje srpskog stanovništva u NDH, a nakon takvih ciljanih skupina prešlo se na iseljavanje srpskog stanovništva u širem smislu preko sabirnih logora (ibid.: 138).

Dana 25. travnja propisana je Zakonska odredba o zabrani ćirilice (NDH, 1941: 60), 30. travnja Zakonska odredba o rasnoj pripadnosti te Zakonska odredba o zaštiti arijske krvi i časti Hrvatskog naroda (ibid.: 109) kojima je pokrenut projekt istrebljenja Židova i Roma, a 3. svibnja propisana je Zakonska odredba o prijelazu s jedne vjere na drugu (ibid.: 157). I Srbima i Židovima je naredbom od 7. svibnja ograničeno kretanje u Zagrebu, a iz grada su mogli izlaziti samo u posebnim okolnostima (Hrvatski glas, 1941: 2). Dućani i obrti Židova i Srba su konfiscirani, a na njihova mjesta dolazili su ustaški povjerenici.

Osim što se opisanim iseljavanjem državni teritorij praznio od Srba, druga korist za vlasti NDH bila je ta što se na takav način dolazilo do njihove imovine. U slučaju imućnijih Židova i Srba te njihovih organizacija tu se radilo o zaista znatnim novčanim sredstvima, nekretninama i pokretninama. Ta pljačka nastojala se legalizirati, pa su donesene zakonske odredbe slijedom kojih imovina iseljenih osoba postaje državno vlasništvo. Na imućnije Židove i Srbe ciljalo se i 10. svibnja kada je određeno da svi Židovi i Srbi moraju napustiti područje Zagreba sjeverno od Maksimirske ceste, Vlaške ulice i Ilice ( ibid.), što se držalo bogatijim dijelom grada. Osim navedenog organiziranog prisilnog iseljavanja, mnogi su se Srbi samoinicijativno dali u bijeg u Srbiju. U listopadu pak dolazi do opadanja i naposljetku obustave cije$\log$ državno ordiniranog projekta prisilnog iseljavanja, dobrim dijelom i zato što je to njemačkim okupacijskim snagama u Beogradu počelo predstavljati teret (Škiljan, 2012: 29). Cijeli taj proces pratila je snažna antižidovska i antisrpska propaganda, koja je u kasnijim godinama rata počela jenjavati dijelom zato što su se ustaške vlasti sa Židovima i Srbima već u znatnoj mjeri i na razne načine obračunale, a dijelom i zato što su se morale posvetiti za njih opasnijim neprijateljima - partizanima i savezničkim silama (Škiljan, 2014: 57).

Za prelaženje s pravoslavlja na katoličanstvo bio je zadužen vjerski ured Državnog ravnateljstva za ponovu NDH, koji je 30. srpnja 1941. objavio naputke po kojima se vrši prekrštavanje. Pokrenuta je kampanja prisilnog prekrštavanja, koje se ponekad obavljalo i en masse, pri čemu bi cijela sela bila odjednom prekrštena (ibid.: 104). U tom stanju opće nesigurnosti mnogi Srbi i Židovi računali su na to da će spasiti živote sebe i svojih obitelji ako se odluče za prekrštavanje, odnosno po- 
krštavanje, pa su se i “dobrovoljno” javljali za taj obred, mada sam taj čin svejedno mnoge nije spasio (Goldstein, 2001: 479). Pored prekrštavanja i pokrštavanja rušile su se i bogomolje, kako pravoslavne crkve i manastiri tako i sinagoge, a 22. svibnja izdana je odredba svim zagrebačkim Židovima da moraju na vidna mjesta na odjeći pričvrstiti žuti znak sa slovom “Ž”” (ibid.: 125).

Uz vjerski život ograničavao se i kulturno-obrazovni, pa je oduzimana imovina raznim srpskim i židovskim društvima, a 3. lipnja ukinute su i srpske pučke škole (Zatezalo, 2007: 60). Naredbom od 7. lipnja počinju se prikupljati podaci o Srbima koji su se doselili u Hrvatsku nakon 1900. godine (ibid.: 60). Usporedo s tim rađeni su i drugi popisi, kao npr. oni sastavljeni po naputku Ravnateljstva ustaškog redarstva NDH od 23. srpnja, po kojem su organi lokalne vlasti bili dužni napraviti popise Srba pod svojom upravom, što je kasnije korišteno u provođenju terora (Škiljan, 2014: 58). Naziv srpskopravoslavna vjera promijenjen je 18. srpnja u grčkoistočna, a 5. prosinca ukinut je julijanski kalendar (Matković, 2002: 128).

S nepoćudnim skupinama u NDH vrlo se rano počelo obračunavati i ubojstvima. Prva veća masovna ubojstva počinjena su 27-28. travnja kada su u Gudovcu ubijene 192 osobe (Tomasevich, 2001: 398), 5-9. svibnja kada je u Blagaju ubijeno više od 500 osoba (Opačić, 1988: 153) te 12-13. svibnja kada je u okolici Gline ubijeno više od 350 ljudi srpskog porijekla (Mrkalj, 2018: 136).

\section{Logor "Danica" te prve deportacije u logore i zločini u NDH}

Prvi ustaški koncentracijski logor osnovan je 15. travnja blizu Koprivnice u bivšoj Tvornici kemijskih proizvoda "Danica", čije je ime preuzeo i sam logor. Glavni ustaški stan je pripadnika Poglavnikove tjelesne bojne Stjepana Pižetu postavio kao zapovjednika logora, a prva velika skupina zatočenika dovedena je u "Danicu" 29. travnja, nakon što je preko Zagreba dopremljeno preko 500 Srba uhapšenih tri dana ranije u Grubišnom Polju. Oni su tijekom lipnja i srpnja otpremljeni u sustav logora Gospić-Jadovno-Pag te ondje ubijeni (Dizdar, 2017: 646; Zatezalo, 2007: 44).

Narednih mjeseci logor se ubrzano puni Židovima, Srbima, Romima, hrvatskim antifašistima, komunistima i ostalima, a do sada je utvrđeno 4.336 osoba koje su prošle kroz logor, s tim da je 2.167 od njih kasnije život izgubilo u gospićkom sustavu logora (Dizdar, 2017: 650). Po svojoj namjeni "Danica" nije bila logor smrti, nego sabirno-tranzitni logor, ali su zlostavljanja, mučenja i silovanja bila učestala. Najveći broj logoraša na kraju je deportiran u neki od drugih logora u NDH. Sa slanjem zatvorenika prema Gospiću počelo se 30. lipnja, prema Jasenovcu u prosincu, a "Danica" se zatvara u rujnu 1942. 


\section{Objekti sustava logora Gospić-Jadovno-Pag}

Prvi objekt budućeg sustava logora Gospić-Jadovno-Pag bila je kaznionica Okružnog suda u Gospiću, ranije poznata kao "Gericht”. Kao što je to bio slučaj s brojnim drugim zatvorima Kraljevine Jugoslavije, ustaše su preuzeli kontrolu i nad "Gerichtom" te su tamo počeli dovoditi najprije Srbe i hrvatske komuniste, a nakon toga i Židove (Zatezalo, 2007: 105). Formalno se kaznionica nazivala Koncentracijski logor Gospić, iako je po svojoj namjeni bio sabirno-tranzitni, s obzirom na to da su se zatvorenici u njemu relativno kratko zadržavali, skučeni u velikom broju po ćelijama, hodnicima i u samom dvorištu, gdje je u jednom trenutku moglo biti zatočeno preko 2.000 osoba. Službeno naređenje o osnivanju logora izdano je tek 2. lipnja, no realno je kaznionica do tada već primila određen broj zatočenika. Za zapovjednika Koncentracijskog logora Gospić postavljen je ravnatelj Župskog redarstvenog ravnateljstva u Gospiću Stjepan Rubinić, upravitelj same kaznionice bio je Milan Staraček, a logor su osiguravali članovi ustaške vojnice kojima je zapovijedao Juco Rukavina (ibid.: 106). Centrala u Gospiću, u koju su zatvorenici dopremani iz čitave NDH, kasnije je dopunjena logorima na Velebitu i Pagu (Peršen, 1966: 42). Iz Gospića su zatočenici redovito slani u te druge logore, pa je i iz toga razvidno da svi ti logori nisu bile nekakve odvojene i nekoordinirane jedinice, nego da je bila riječ o međusobno povezanom sustavu logora sa zajedničkim ciljem.

Zatvorenici su vlakovima dopremani u Gospić iz cijele NDH u sve većem broju, pa se već na gospićkoj željezničkoj stanici javila potreba za njihovim smještanjem. Sav taj proces primanja zatvorenika i njihovog usmjeravanja prema drugim logorima u sklopu sustava zahtijevao je da se na željezničkoj stanici uspostavi jedan ograđeni prostor za zatočenike, ali su oni, u slučajevima kada bi pristigli veći transporti, bili razmješteni i po drugim mjestima u gradu (Goldstein, 2001: 280). Po svemu sudeći, zatvorenici su se tu kratko zadržavali dok nisu kamionima, autobusima ili pješice upućeni na neku drugu lokaciju, a takve kolone učestalo su napuštale Gospić (Zdunić Lav, 1989: 183).

Mada su zatvorenici redovito otpravljani iz Gospića prema Velebitu, čime se kaznionica konstantno praznila, dotok zatočenika bio je tako velik da se javila potreba za još jednim ovećim zbirnim logorom. Oko tri kilometra od kaznionice staje jednog ubijenog lokalnog trgovca prenamijenjene su za prihvat zatočenika i postale sabirni logor koji su zatvorenici prozvali "Ovčara”. Logor je uspostavljen u lipnju, a njime je upravljao Dragutin Pudić Paraliza. U tom je logoru boravilo i do 1.500 zatvorenika, ali nisu se vršila masovna ubojstva, iako su zlostavljanja bila učestala (ibid.: 182).

Najveći dio puta od Gospića do ostalih logora u sustavu protezao se kroz slabo naseljeno područje koje je jednim dijelom bilo prekriveno šumom, a kako se staza 
približavala Podvelebitskom kanalu, šumu je sve više zamjenjivao krški reljef. Na jednom velebitskom proplanku usred guste šume zapadno od Gospića uspostavljen je logor Jadovno, u koji su dovođeni brojni Srbi, Židovi i hrvatski komunisti da bi bili ubijeni na nekom od obližnjih gubilišta. Upravitelj je bio Rude Ritz, s Antom Bešlićem kao zapovjednikom obezbjeđenja (Goldstein, 2007: 240). Logor se nalazio na nadmorskoj visini od cca 1.200 metara, izgradili su ga sami zatvorenici, a finalno proširenje provedeno je 24. lipnja (Zatezalo, 2007: 115). Smještajnih objekata u početku nije bilo, nego su zatočenici spavali na otvorenom te su konstantno bili izloženi vremenskim nepogodama. S obzirom na to da na raspolaganju nije bilo pokrivača, a od odjeće su imali samo ono što su ponijeli sa sobom, spavalo se na zemlji, pa su noći zbog hladnoće bile osobito neugodne. Tek sredinom srpnja zatvorenici podižu dva metra visoke nadstrešice pokrivene granjem. S konstantnim priljevom logoraša broj tih nadstrešica je rastao, a bile su podijeljene na srpski, židovski i komunistički dio. Procjenjuje se da je kapacitet logora bio oko 2.000 ljudi, ali se stalno praznio i punio novim logorašima (Goldstein, 2007: 239). Hrane je bilo jako malo, samo jedan nedostatan obrok dnevno, a logoraši su povrh toga sudjelovali u šumskim radovima u okolici logora. Kombinacija takvih surovih uvjeta i zlostavljanja iscrpljivala je logoraše, $i$ to namjerno, kako ne bi pružali otpor kada budu odvedeni na likvidaciju.

Kako je dotok zatvorenika iz cijele NDH u Gospić bivao sve veći, kapaciteti u logoru Jadovno i logorima na Pagu (o kojima će biti riječi kasnije) postali su nedovoljni, pa se javila potreba za uspostavljanjem još jednog logora u okviru kojeg bi se vršile likvidacije. U blizini Baških Oštarija, koje se nalaze na prometnici od Gospića do Karlobaga, početkom srpnja osnovan je pomoćni logor Stupačinovo pod upraviteljem Ivanom Devčićem Pivcem (Zatezalo, 2007: 155). Ta lokacija odabrana je upravo zbog dobre povezanosti s Gospićem, kao i zbog toga što je u blizini bilo nekoliko jama, gdje su onda ubijani zatočenici.

Područje od Gospića do Karlobaga odabrano je kao pogodno za osnivanje logora smrti vjerojatno zato što je slabo naseljeno i daleko od očiju javnosti te zato što obiluje kraškim jamama u koje su se mogle bacati žrtve. Locirane su brojne takve jame, dok su speleološki istražene samo poneke. Osim stradanja vezanih konkretno uz logorski sustav Gospić-Jadovno-Pag zločini su se činili i u širokoj oblasti oko Gospića i na Velebitu (npr. Arbanas, 1989; Rajčević, 1989). Mada žrtve stradale u tim zločinima nisu prošle kroz sustav logora, one spadaju u širi okvir terora nad civilnim stanovništvom na tom području.

Nakon proglašenja "rasnih zakona" pod MUP-om NDH osniva se Ravnateljstvo za javni red i sigurnost s ciljem provođenja tih zakona, a u sklopu Ravnateljstva uspostavlja se Ured III Ustaške obrane za osiguranje sa zadatkom osnivanja i upravljanja koncentracijskim logorima. Mijo Babić, kao šef Ureda III, sastao se s 
lokalnim predstavnicima vlasti na Pagu krajem svibnja ili početkom lipnja ne bi li od njih dobio savjet gdje da se na otoku osnuje logor, čija bi navodna svrha bila izgradnja puta (Zatezalo, 2007: 126).

Nakon što je lokacija odabrana, počelo se s pripremama za osnivanje logora te je 25. lipnja u Bašku Slanu na otoku Pagu pristigla prva skupina logoraša, 30-ak Židova uhapšenih tri dana ranije u Zagrebu. Pod komandom Ivana Devčića Pivca, logor je bio smješten u Paškom zaljevu na pustom kamenitom području izloženom oštrim vremenskim uvjetima i bio je podijeljen na dva dijela, muški (Slana) i ženski (Metajna), s tim da je muški bio dodatno podijeljen na židovski i srpski dio (Goldstein, 2001: 284). Muški logor bio je opasan žicom, a smještajne mogućnosti bile su nedostatne, pa je većina zatvorenika bila izložena nesnosnim vrućinama. Kao i u slučaju Jadovna, zatočenici su bili uključeni u iscrpljujuće fizičke radove po velikim vrućinama, u ovom slučaju na izgradnji puta. Ženski logor u selu Metajna bio je smješten u dvije prenamijenjene vikendice, a kasnije je proširen i na još jednu seljačku kuću. Prve četiri zatočenice stigle su sa svojim supružnicima 25. lipnja, nakon čega su odvojene od njih u zaseban logor kojim je upravljao Maks Očić (Zemljar, 1988: 53). Kasnije je kroz logor prošlo mnogo žena i njihove djece, a silovanja, mučenja i ubijanja često su se događala (Goldstein, 2001: 282-293).

Ali nisu svi zatočenici koji su trabakulima i bracerama slani iz Karlobaga za Pag dospjeli u logore. Neki su opljačkani i ubijeni već putem i bacani u more ili u jame na visoravni Furnaža (Peršen, 1966: 43). Uz Furnažu, žrtve su dovođene, ubijane i pokapane i na još nekoliko lokacija na tom dijelu Paga.

\section{Zatvaranje sustava logora Gospić-Jadovno-Pag}

S obzirom na to da su se ustaški zločini nizali jedan za drugim u široj sferi djelovanja sustava logora Gospić-Jadovno-Pag, ali i na području cijele NDH, dio srpskog stanovništva predvođen Komunističkom partijom diže se na ustanak u srpnju 1941. na području Like i Banije. Ustanak se brzo širio, a ustaški režim nije ga mogao obuzdati, pa je postao prijetnja interesima fašističke Italije na tom teritoriju. Zato je 15. kolovoza talijanska II. armija krenula u reokupaciju Zone II, čime je Italiji vraćena vojna i civilna vlast na tom području. Mada je fašistička Italija i prethodno bila upućena u razmjere terora koji su provodili ustaše, reakcija progonjenog srpskog stanovništva pokazala se isuviše snažnom, pa su sada talijanske snage počele raditi na suzbijanju ustaških zločina (Goldstein, 2007: 243). Imajući to na umu, ustaše su sustav logora Gospić-Jadovno-Pag počeli užurbano zatvarati i prazniti, a posljednji zatvorenici su krajem kolovoza ili ubijani ili slani u druge logore po NDH, izvan domene talijanskog utjecaja, pa su tako neki od posljednjih zatvorenika sustava logora Gospić-Jadovno-Pag ujedno bili i među prvim logorašima Jasenovca (Goldstein, 2001: 291). 
Pokušavalo se i prikriti tragove zločina u sustavu logora Gospić-Jadovno-Pag, ali su oni ipak bili toliko veliki da to nije bilo ostvarivo (Zemljar, 1988: 221). Štoviše, u jame je bilo pobacano toliko ljudi da je postojala opasnost od zagađivanja pitkih voda na tom području. Talijanska vojska reagirala je sastavljanjem inspekcijsko-sanitarnog tima koji je imao zadatak ispitati i neutralizirati taj slučaj trovanja voda. Direktor medicinske službe V. korpusa II. talijanske armije, pukovnik liječnik Muzio Fiorini, šalje potporučnika, također liječnika, Vittoria Finderlea u inspekciju terena i eventualnu higijensku sanaciju. Dana 1. rujna Finderle sa svojim timom kreće u obilazak područja na kojem su djelovali logori sustava Gospić-Jadovno-Pag i zadržava se na zadatku do 5. rujna. Nakon što je obišao teren i napravio sanaciju onih lokaliteta koje je uspio pronaći, napisao je izvještaj na temelju kojeg je jedinica zdravstvene službe divizije "Re" 11. rujna pod poručnikom Santom Stazzijem krenula na Pag i sljedećih deset dana radila na otkrivanju i spaljivanju leševa iz masovnih grobnica (ibid.: 234-244).

\section{Emocije u svjedočanstvima preživjelih iz sustava logora Gospić-Jadovno-Pag}

U analizi je korišteno devet iskaza preživjelih objavljenih u knjizi Radio sam svoj seljački i kovački posao Đure Zatezala, pet iskaza objavljenih u knjizi Haron i sudbine Ante Zemljara i šest svjedočanstava objavljenih u knjizi Đure Zatezala Jadovno - kompleks ustaških logora 1941. Najraniji iskaz, onaj Jelene Basarić zapisan je 1942. u Beogradu, dok je rat još trajao (Zatezalo, 2005: 259), a posljednji su prikupljeni 1990. godine. Emocija koja se u svjedočanstvima najčešće javlja je strah, a prepoznate su i emocije iznenađenja, strepnje, nemoći, očaja i rezignacije, čuđenja, zaprepaštenja, nade, radosti i žalosti. U nekim iskazima emocija nije precizno imenovana, već su samo opisane fiziološke reakcije poput drhtanja i udaranja srca. Ponegdje se konkretna emocija može iščitati iz opisa ponašanja kazivača, na primjer kad se strah čovjeka odbjeglog iz logora od bilo kakve ljudske prisutnosti dočarava njegovim skrivanjem u grmlju prilikom prolaska seljaka (ibid.: 300).

Opisi emocija češći su u svjedočanstvima koja su zapisana nakon dužeg vremenskog razdoblja, dok se svjedoci čija su svjedočanstva zapisana ranije nastoje držati činjenica. Naravno, odsutnost konkretnih verbalnih emotiva ne znači da je sam iskaz bio lišen potencijalnih neverbalnih emotivnih sadržaja, no budući da ljudi koji su zapisivali ta rana svjedočanstva nisu opisivali neverbalne elemente komunikacije, ne možemo znati u kojoj je mjeri neverbalizirana emocija bila prisutna $u$ navedenim iskazima. Uzroci češćem spominjanju emocija u kasnijim zapisima mogu biti mnogostruki. Moguće je da su nakon prolaska određenog vremena svjedoci mogli bolje procesuirati vlastite uspomene i tako osvijestiti emocionalni sadržaj vlastitog emotivnog iskustva. Sámo reflektiranje o emocijama moglo je dati osjećaju njegovu potrebnu verbalnu artikulaciju. Ulogu je mogla imati i promjena kultur- 
nog stava prema emocijama; iskazivanje određenih emocija poput straha ili tuge s vremenom je postalo društveno prihvatljivije, pa su kazivači bili spremniji govoriti o njima. Kulturni povjesničar emocija Peter Stearns u svojoj je studiji koja se bavi praksama odgajanja djece pokazao kako su u SAD-u od 1930-ih godina potiskivanje i poricanje straha kod djece sve više zamjenjivale tehnike nošenja sa strahom (Stearns, 2003: 25). Jedan od razloga za tu promjenu stava prema strahu bila je sve veća raširenost govora o strahu i traumi u javnosti, od npr. udžbenika za odgoj djece do psihološkog i psihoanalitičkog diskursa koji je bio sve prisutniji i u laičkim krugovima. U mjeri u kojoj je promjena odnosa prema strahu bila povezana s modernizacijom društva, moguće je da se slična promjena dogodila i u jugoslavenskom društvu u drugoj polovici dvadesetog stoljeća. Na kraju, pojava partizanske histerije u vojnim bolnicama neposredno nakon Drugog svjetskog rata učinila je ratnu traumu vidljivijom, a daljnja modernizacija i postupno otvaranje društva mogli su izmijeniti način na koji se u društvu govorilo o emocijama i na koji se shvaćalo javno iskazivanje emocija. Treća mogućnost koja je mogla utjecati na spremnije govorenje o emocijama jest drugačiji kontekst davanja iskaza. Dok je ranijim svjedočenjima kontekst često bio utvrđivanje krivnje za ratni zločin, svrha kasnijih bilo je ukazivanje na patnju žrtava ustaških zločina kako bi ih humanizirala i stvorila efekt suosjećanja kod onih koji će ta svjedočanstva čitati. To je naročito karakteristično za svjedočenja zapisana kasnih osamdesetih i na početku devedesetih godina u jeku buđenja nacionalističkih ideologija.

Na početku rada istaknuli smo da se osjećaji straha i strepnje često isprepliću u iskazima o osjećajima. Za Delumeauovo razlikovanje straha i strepnje bitno je postoji li objekt na koji je emocija fokusirana. Ako postoji određeni objekt od kojeg možemo pobjeći ili mu se suprotstaviti, govorimo o strahu, dok je za strepnju karakteristično da se doživljava kao bolno iščekivanje neke opasnosti. Samim time, Delumeau smatra sam strah manje traumatičnim, dok dugotrajna strepnja često prelazi u neurozu (Delimo, 2003: 37-38).

Strah se u svjedočanstvima najčešće opisuje glagolima "plašiti se" i "bojati se". Ponekad se neki prizor opisuje kao "jeziv" ili "strašan". U prvom slučaju, kada kazivač govori da se nečega "plašio" ili "bojao", obično mu prijeti direktna opasnost. Budući da su kazivači gotovo u pravilu bili ljudi koji su izbjegli sigurnu smrt, emotivi koji referiraju na strah prisutni su u gotovo svim iskazima. U mnogim iskazima strah se javlja u trenutku u kojem žrtve shvate da ih se vodi na mjesto egzekucije. Mane Čanak je u iskazu koji je dao 1944. izjavio da se strah kod njega javio kad mu je Mile Rukavina, jedan od ustaša koji ga je uhapsio, rekao da ga vode u Janjče:

Jako sam se uplašio jer sam ranije čuo da na Janjči ima bezdana jama gdje ustaše ubijaju Srbe i bacaju ih u bezdanušu. (Zatezalo, 2005: 260) 
Nevenka Glumičić Lastavica također opisuje strah koji se u njoj javio kada su ustaše vodile nju i njene suseljane prema bezdanoj jami na Kosi. Ona svoj strah izražava i opisom fiziološke reakcije: "Strah me poduze i počeše koljena klecati" (ibid.: 288). Nakon što su ih njihovi krvnici doveli na Kosu, odvojili su skupinu od deset vezanih ljudi i čuli su se pucnji, što je izazvalo burnu emotivnu reakciju koju Glumičić Lastavica slikovito opisuje kao "dreku, bugarenje i komešanje” (ibid.).

U rečenim primjerima direktan objekt straha su ustaški egzekutori koji su imali apsolutnu moć nad žrtvama, a strah se javlja u trenutku kad žrtve shvate njihovu ubilačku intenciju. No, u nekim svjedočanstvima strah postaje mnogo apstraktniji. Vojislav Mileusnić je 26. lipnja 1941. pobjegao s mjesta masakra Srba na Kuku. Prepričavajući svoja iskustva nakon bijega, Mileusnić brojnim emotivima opisuje strah koji je osjećao otkad je pobjegao. Isprva se bojao da ga ne otkriju, a o intenzitetu njegovog straha govori i činjenica da se bojao da ga ne oda preglasno lupanje srca:

U meni je snažno udaralo, disao sam ubrzano. Na momente zaustavljao sam dah i pritiskivao srce na zemlju, strahujući da me ne čuju. (ibid.: 299)

U trenutku straha Mileusnić se jasno sjećao fizioloških znakova straha, i to upravo zato što je zbog samog straha za goli život postao opsesivno svjestan glasnoće svog disanja i jačine udaraca svog srca. Kasnije, nakon noći provedene u šumi, Mileusnić susreće stočara koji postaje objekt njegovog straha jer se boji da bi stanovnici obližnjih hrvatskih sela mogli biti ustaški agenti:

Dan me prilično ohrabrio, ali su me noge i ruke, i svi dijelovi tijela boljeli, a ruke bile još uvijek okovane. Izišao sam na čistinu ispred šume i ugledao jednog čovjeka kako cestom prema Kuku goni goveda na pašu. Sklonio sam se u grmlje za svaki slučaj jer je govedar nailazio ravno prema meni, s motikom na ramenu. Stotinjak metara niže on je ostavio goveda da pasu i uputio se u dražicu pored ceste, na njivu zasijanu krumpirom. S udaljenosti od dvjesto metara dugo sam posmatrao tog čovjeka, dok je okopavao krumpir, pokušavajući procijeniti ko bi to mogao biti i da li bih mu smio prići i zatražiti pomoć. Znao sam da u Lapcu i okolini ima ustaša, njihovih agenata Hrvata pa sam se plašio da ne naletim na njih. (ibid.: 300)

Zanimljivo je da se komunikacija između Mileusnića i stočara uspostavlja tek kad Mileusnić postane svjestan da se i stočar boji njega:

Prilazio sam mu sa strane, pa me nagnut za motikom, nije ni primijetio sve dok mu nisam nazvao dobro jutro. To ga je preplašilo i trgnulo kao da je nečim udaren, a tek je postao zbunjen kad je pred sobom vidio čovjeka grozno okrvavljenog i u zgužvanom odijelu. Motika mu je ispala iz ruku. Videći njegov strah, i bojeći se da ne počne bježati, a ja ostanem u žičanom okovu, rekoh: "Ne boj se, čovječe, vidiš li da sam pobjegao sa strijeljanja." Tek tada se malo pribrao i smirio. Prišli 
smo jedan drugome, ali je on stalno pogledavao na cestu, bojeći se da ne naiđu ustaše. (ibid.)

Mileusnić u svom strahu često zdvaja nad etničkom pripadnošću ljudi koje sreće. Kad mu nakon susreta sa stočarom koji mu je odvezao ruke priđu dvije žene, on spominje kako se bojao jer je jedna od njih "imala čudan naglasak" (ibid.: 301). Sličan se strah od Hrvata javlja i kod Mane Čanka. Nakon bijega iz Jadovna Čanak prolazi pored jedne kuće i prisluškuje razgovor ukućana. Po govoru zaključivši da se radi o Hrvatima, Čanak odlučuje da im se neće javiti (ibid.: 262). Kasnije, doduše, Čanak nailazi na skupinu muškaraca za koje zaključi da su Srbi, pa im se također ne javlja, već se prvi put javi jednoj ženi koju pita za put do Počitelja, gdje je živjela njegova sestra (ibid.: 263).

Mileusnićevo traumatično iskustvo natjeralo ga je da počne razmišljati o nacionalnosti čovjeka kojeg je slučajno sreo. Budući da su žrtve ustaškog terora bile obilježene i viktimizirane zbog svoje nacionalne pripadnosti, za njih i nacionalna pripadnost Drugog postaje pitanje života ili smrti. Možemo reći da su strah i trauma učinili etničku podjelu vidljivom i stvarnom kako za zločince tako i za žrtve zločina. Kao što je Max Bergholz pokazao u svojoj studiji o motivima nasilja u Kulen Vakufu za vrijeme Drugog svjetskog rata, nacionalizam ne samo da proizvodi etnički motivirano nasilje već i samo iskustvo nasilja dovodi do (re)konceptualiziranja svijeta u svjetlu nacionalnih podjela. Time se stvara kontekst za potencijalne buduće etničke konflikte ili za međuetničku solidarnost (Bergholz, 2016: 296). Iskustvo straha od osoba drugog etniciteta nekad se može transformirati u isticanje važnosti međuetničke solidarnosti, što se vidi na ranije navedenom primjeru svjedočanstva Steve Brakusa.

Ponekad se strah manifestira u obliku strave ili jeze prilikom svjedočenja o posljedicama ustaškog zločina. U tom slučaju traumatičan je susret s dokazima počinjenog nasilja i shvaćanje na koliki su opseg nasilja ustaše bili spremni. Maksim Dimić u svojoj izjavi 23. veljače 1943. godine govori o načinima na koje su ustaše mučili zatočene Srbe te jasno izražava kako su ti prizori bili previše užasni da bi ih se prisjećao. Emotivi kojima opisuje taj osjećaj kolokvijalni su opis fiziološke reakcije karakteristične za strah:

Bilo je i drugih užasnih mučenja, ali sve to sada ne mogu ni iznijeti, jer se sav od užasa uzbudim i kad na sve to pomislim, kosa mi se podiže na glavi. (Zatezalo, 2007: 303)

Mićo Jelača, koji je svjedočio transportima brojnih zatočenika kroz Gospić, ne opisuje svoje emocije detaljno, ali svejedno govori kako su kolone na njega imale "strašan utisak" (ibid.: 121). 
Ponekad se užas miješa s izrazima sažaljenja prema žrtvama ili im posve ustupa mjesto. Jelena Basarić tako kolonu u kojoj se zatočenici kreću prema gubilištu opisuje kao “žalosnu kolonu” (Zatezalo, 2005: 268), dok se Josip Balaž sjeća izgladnjele židovske djece opisujući prizor kao "dirljiv" i "jeziv" (Zemljar, 1988: 91). Iako obuzeti strahom, preživjeli često spominju trenutke suosjećanja sa svojim supatnicima. Mileusnić tako kaže kako je bilo teško slušati kuknjavu žena "a muškaraca još teže" (Zatezalo, 2005: 297), a Sonja Lukić spominje plač kao nešto što povezuje različite skupine koje su patile od ustaškog terora i stvara svojevrsnu solidarnost patnje (Zemljar, 1988: 133).

Uz strah u svjedočanstvima se često javlja strepnja pred neizvjesnom sudbinom koja je često povezana s osjećajem bespomoćnosti, očajem i rezignacijom zbog potpunog ili djelomičnog gubitka kontrole žrtava nad vlastitom sudbinom. Osjećaj "bespomoćnosti pred neposrednom prijetnjom uništenja je u korijenu iskustva traume" (Greenspan i dr., 2014: 68). U već citiranom svjedočanstvu Petar Pavlica ne imenuje osjećaj bespomoćnosti direktno, već ga dočarava citiranom usporedbom sa stokom koja ide u klaonicu.

Strepnju u svom svjedočanstvu na nekoliko mjesta izražava i Vojislav Mileusnić. Nakon što su ustaše njega i njegove suseljane vezali žicom, Mileusnić opisuje bol koju je osjetio, a svoje emotivno stanje opisuje jednostavnom konstatacijom kako se "nije moglo očekivati ništa dobro" (ibid.: 297).

Oto Radan u nekoliko navrata govori o trenucima u kojima je stalna strepnja prešla u potpunu rezignaciju i gubitak vjere u izvjesnost vlastitog preživljavanja. Kao da su perzistentnost $\mathrm{i}$ intenzitet traumatičnog iskustva rezultirali postepenim otupljivanjem afekta:

Postalo nam je svejedno gdje smo i koliko će to trajati. Izlaza smo vidjeli sve manje. Ispočetka se još nešto razgovaralo, politiziralo, nadalo se nekom izlazu, međutim, to je brzo zamrlo i jedini nam je bio interes saznati da li smo još uvijek svi od juče živi i koliko nas je ostalo još donekle krepkih. (Zemljar, 1988: 56)

Osjećaj rezignacije koji se javio kod Radana ovdje je dočaran emotivima koji asociraju na smrt. Tako politiziranje i nada nisu jednostavno prestali, već "zamrli", i jedini se interes izražava kao prebrojavanje preživjelih. Eventualna smrt postaje izvjesna, pitanje je samo kad će uslijediti, a bilo kakvu dugoročnu nadu zamjenjuje jednostavno preživljavanje iz dana u dan. Radan u svom svjedočanstvu nekoliko puta ističe da se emotivno stanje zatočenika logora smrti Slana sastojalo od posvemašnjeg nedostatka nade:

$\mathrm{Ne}$, ničemu se više nisam nadao. Ja sam bio svjestan da se iz logora neću izvući živ. Kako ostati živ ovdje gdje se svaki čas nekog likvidira, netko nestane? (ibid.: 
Strepnja, očaj i užas kod mnogih su rezultirali emotivnom patnjom koju je bilo teško podnijeti. Mnogi su izlaz iz traumatične situacije tražili u samoubojstvu. Milan Bogdanović, svjedok užasa gospićke kaznionice, govori o samoubojstvu svećenika Petra Majstorovića koji se objesio u zatvoru jer "nije više mogao slušati jauk Srba koji su bili mučeni po čitave noći”, a na isti se očajnički korak odlučio i njegov sin Milojko (Zatezalo, 2007: 86).

Poneki preživjeli ističu kako se ipak nisu lako prepuštali očaju, već je u njima postojala stalna nada koja ih je držala na životu. Kad Vojislav Mileusnić govori o svom hapšenju od strane ustaša, često ističe kako se nadao bijegu i intenzivno ga planirao. Nada se u njemu rasplamsava u trenutku kad iz razgovora dvojice ustaša shvati da je jedan od zatočenika uspio pobjeći. On ju opisuje kao iznenadan nalet energije koja ga obuzima:

U mene je nadolazila neka čudna snaga. Šapnuo sam Stevi Rajaku, koji je ležao pored mene, da ću i ja bježati. Na to mi je on odgovorio: "Kako, jadna ti majka, ovako vezanih ruku i nogu." Ništa mu nisam odgovorio, ćutao sam, ali s nadom. (Zatezalo, 2005: 298)

U trenutku svog bijega s mjesta pokolja u Mileusniću se konstantno bore strepnja i nada. Tako strahuje zbog vlastitog disanja i otkucaja srca, ali nakon što proboravi noć u šumi a da nije bio uhvaćen, Mileusnić veoma eksplicitno opisuje vlastitu nadu i osjećaj sreće:

Stajao sam i osluškivao razmišljajući i ne vjerujući u sve ovo čudo. Oko mene se zora polako budila i čulo se ono prvo usamljeno jutarnje pjevanje ptica. (ibid.: 299)

Mileusnić svoju radost i iznenađenje zbog toga što je usprkos svemu uspio pobjeći dodatno dočarava svojim zapažanjima. U prvim trenucima zore nakon noći pokolja od kojeg je pobjegao zapaža "usamljeno pjevanje ptica" koje stoji u kontrastu s jaucima žrtava i psovkama ustaških krvnika. Svoju radost Mileusnić će još jednom istaknuti u trenutku kad je došao na rub šume:

Stojim i gledam kako se dan širi, to i pogled sve dalje seže. U meni zaiskri radost. Prepoznao sam Donji Lapac i sela oko njega. Vidio sam ceste koje su povezivale Lapac sa Bihaćem i Srbom, a ja sam na cesti prema Udbini. Stajao sam tako na mjestu zaklonjen u grmu i čekao da netko naiđe jer se nisam smio udaljiti od šume. (ibid.: 300)

Većina svjedoka nije imala ni ranije iskustvo ni predodžbu o progonu kakav je vršio fašistički režim. Ideja orkestriranog progona motiviranog rasističkim teorijama i etničkom mržnjom, kojem je konačni cilj fizičko uništenje jedne skupine ljudi, bila im je nepojmljiva. Zbog toga mnoga svjedočanstva govore o iznenađenju i za- 
prepaštenju žrtava. Oto Radan prenosi riječi zagrebačkog odvjetnika Ferde Franka koji je za vrijeme tamnovanja u Slanom cijelo vrijeme ponavljao:

Ne ide mi u glavu, ali zašto, zašto su me uhapsili. Pa ja za cijeloga svoga života nisam bio ni pod kakvim disciplinskim postupkom. (Zemljar, 1988: 55)

Uglednom i poštovanom vremešnom odvjetniku bilo je nepojmljivo da rasistički karakter ustaškog režima ne operira po parametrima pravne države i da je ustašama bio cilj uništiti ga, a ne kazniti za neki zločin. Sportaš Zlatko Vajler pokušavao je psihologizirati i racionalizirati činjenicu da većina žrtava nije mogla anticipirati zločine:

To je uglavnom bilo i sa psihologijom mase, nas koji prije nismo politički dovoljno živjeli, nego smo bili onako rezultat jedne malograđanske sredine koja se bavila svojim određenim poslom, sportom, koji su živjeli u uvjerenju da nikad nisu nikoga prevarili, da nisu bili nepošteni prema drugome, prema tome što im se može dogoditi nego da na dva tjedna idu u logor a onda će opet biti sve u redu. (ibid.: 147)

Emotivnu nepripremljenost na užase genocida Vajler argumentira nedostatkom političkog života, no kasnije će u okviru istog iskaza istaknuti drugu pretpostavku:

... međutim, čovjek je kao i bolesnik od raka, svjestan je da treba da umre, ali odbija onu spoznaju da je bolestan. (ibid.)

Vajler u svom iskazu mnogo vremena posvećuje promišljanju činjenice da je genocid populaciju mladih zagrebačkih Židova dočekao nespremnima i naizmjence ju pripisuje političkom neiskustvu i obrambenom mehanizmu poricanja. Primjer poricanja nalazimo i u svjedočanstvu Glumičić Lastavice:

Nikola glasno povika: “Ubijaju.” Nasta dreka, bugarenje (lelek), komešanje. Kroz čudan i plačljiv glas reče baba Marta: "Muči sunce bakino, ta neće nas stare i nejake." Ovo povrati malo daha i nade u život mnogima, ali to samo za sekundu. (Zatezalo, 2005: 288)

Ton glasa navedene "babe Marte" i činjenica da je njena izjava povratila nadu seljanima, iako su neposredno prije njene izjave odjekivali plotuni iz pušaka, govori o tome da je ona posegnula za poricanjem radi olakšavanja vlastite emotivne patnje, što je velik broj žrtava u trenutku očaja odlučio prihvatiti.

\section{Zaključak}

Usprkos velikim stradanjima koja su se dogodila u okviru sustava logora GospićJadovno-Pag, trebalo je proći dugo vremena da se sjećanje na te događaje usustavi (podsjetimo npr. da je Odbor za podizanje spomen obilježja logora Jadovno osno- 
van tek 1985. godine). Taj podatak još je interesantniji uzme li se u obzir da su na rasplamsavanje ustanka 1941. godine i posljedično širenje vojnih operacija po NDH - a time i budućnosti ovih krajeva - više utjecali zločini počinjeni u tom logoru (i, jasno, drugdje po NDH u to vrijeme) nego oni koji su došli poslije, a koji su zloglasniji i više prisutni u kolektivnoj memoriji, tj. zločini koje povezujemo s jasenovačkim kompleksom logora. Ako, dakle, razmotrimo te prve mjesece postojanja NDH i teror nad Židovima, Srbima, Romima, hrvatskim antifašistima, komunistima svih etniciteta i ostalima, može se zaključiti da je reakcija progonjenog stanovništva Like i Banije bila neminovna. Prvi odred koji se formirao u svrhu organiziranog otpora prema NDH bio je Prvi sisački partizanski odred, osnovan 22. lipnja 1941. godine, a mjesec dana nakon toga narod sastavljen pretežito od srpskog stanovništva koji se u reakciji na ustaške progone sakrivao po šumama diže se na opći ustanak predvođen Komunističkom partijom i time u NDH započinje borba koja će trajati sljedeće četiri godine. Događaji koji su pokrenuli tu borbu su akcija u Banskom Grabovcu 23. srpnja i ustanak u Srbu 27. srpnja.

Jedno od pitanja vezanih uz gospićki sustav logora koje povjesničarska struka nije uspjela na zadovoljavajući način utvrditi, a možda nikada i neće, svakako su poteškoće oko definiranja preciznog broja ubijenih, pošto procjene drastično variraju od oko 10.000 do više od nevjerojatnih 70.000. Neke od prvih procjena dane su još tokom samog Drugog svjetskog rata, a od tada pa sve do danas javili su se razni autori s raznim metodama procjene broja ubijenih. Tako npr. Dragan Cvetković navodi broj od oko 15.500 na temelju korigiranog popisa žrtava Drugog svjetskog rata iz 1964. godine (Cvetković, 2010: 53); Ivo Goldstein do broja 24.000 dolazi prije svega na osnovi izjave koju je ranije spomenuti Stjepan Rubinić dao književniku Iliji Jakovljeviću dok su bili zajedno zatočeni u Staroj Gradiški (Goldstein, 2001: 301); Franjo Zdunić Lav sa zadrškom ustanovljuje oko 37.000 žrtava na temelju vlastitih opservacija događanja u Gospiću i okolici 1941. godine te naknadnih istraživanja (Zdunić Lav, 1989: 198), a Đuro Zatezalo dolazi do izračuna od oko 40.000 ubijenih bazirajući se na usporedbi arhivske građe pomoću koje je pratio sabiranje nepoćudnih osoba po NDH, njihov transport i na kraju dopremanje u Gospić (Zatezalo, 2007: 405).

Kako se vidi, sve te razne metode dovele su do divergentnih procjena tako da ni danas ne postoji konsenzus po pitanju broja ubijenih u tom sustavu logora, čak i nakon mnogo radova napisanih na tu temu. Iako znatan broj autora navodi brojke između otprilike 30.000 i 40.000 (npr. Uzelac, 1963: 488; Jelić-Butić, 1977: 186; Zdunić Lav, 1989: 198; Zatezalo, 2007: 405), ima i radova (npr. Geiger et al., 2017) koji bacaju sumnju na tako visoke procjene. Računajući na to da će utvrđivanje barem približnog broja ubijenih u sustavu logora Gospić-Jadovno-Pag ljeta 1941. biti izrazito teško jer sačuvana evidencija iz doba funkcioniranja logora ne postoji, 
možda je veća pouka koju za potrebe ovoga rada možemo izvući upravo sama spoznaja o svrsi logora i naravi politike koja se provodila općenito u NDH, pa tako i na Jadovnu. Naime, iz dokumenata je uočljivo da se, kad je riječ o tim logorima, radilo o mnogo većem i sustavnijem poduhvatu od eliminiranja nepoćudnog stanovništva samo iz njihove okolice. Također znamo da je istodobno s projektom Jadovno ustaški režim diljem NDH likvidirao veće skupine ljudi gotovo na licu mjesta a da nisu transportirani negdje daleko, pa stoga postojanje nejasnoća oko točnog broja ubijenih u gospićkom sustavu logora ne umanjuje činjenicu da je intencija za eliminiranjem nepodobnih ljudi zaista postojala (pritom svakako treba upozoravati na svjesne manipulacije ili nesvjesne greške). Uzmu li se u obzir obznane režima NDH (što formalne, što neformalne) po pitanju odnosa spram targetiranih skupina te ako se one dovedu u vezu s ritmom ustaških zločina proljeća i ljeta 1941., postaje razvidno da je jedino ustanak krajem srpnja spriječio da se taj cilj temeljitije ostvari.

O odvođenjima ljudi iz domova, zlostavljanjima i masakrima ostala su potresna svjedočanstva preživjelih. Ako ih analiziramo iz perspektive povijesti emocija, vidjet ćemo da se u njima često miješaju osjećaji straha, očaja, ali i nade i radosti. Prisutnost tih pozitivnih emocija u traumatičnim svjedočanstvima nije nimalo čudna uzmemo li u obzir da se radi o svjedočanstvima ljudi koji su uspjeli pobjeći gotovo sigurnoj smrti. Iako su se svjedočanstva često prikupljala radi utvrđivanja činjenica o ustaškim zločinima, čini se da ni svjedoci ni ljudi koji su zapisali svjedočanstva nisu bježali od više ili manje eksplicitnog izražavanja emocija. Svjedoci često svjesno upliću emocije u svoja sjećanja, dajući do znanja da ih smatraju jednako bitnima kao i činjenice o samom zločinu, kao na primjer u Mileusnićevom slikovitom opisu radosti koju je osjetio kada je uspio pobjeći svojim krvnicima. Ponekad svjedočanstva imaju gotovo hipnotički karakter i svjedoci detaljno opisuju dojmove i emocionalne doživljaje, pa nekad, poneseni asocijacijama, čak naglašavaju kontrast između ranijeg emotivnog stanja ispunjenog radošću i kasnijeg ispunjenog strahom. Takve primjere nalazimo kod Mileusnića i Glumičić Lastavice. Strah, očaj povezan s osjećajem bespomoćnosti i radost nakon bijega upravo su najintenzivnije opisane emocije. Čini se da u većini svjedočanstava one imaju ulogu što vjernijeg prisjećanja određenih događaja koji su kognitivno usko povezani s navedenom emocijom. Neki od doživljaja toliko su povezani da ta emocija nailazi odjeka čak i u opisima prirode, poput veselog pjeva ptica u šumi ujutro nakon Mileusnićevog bijega. Neki svjedoci, poput Petra Pavlice i Ota Radana, govore o tome kako su emocije straha $\mathrm{i}$ bespomoćnosti na njih ostavile trajan trag, te ih godinama nakon događaja mogu ili jasno prizvati u sjećanje ili ih i danas proganjaju. Takvi primjeri svjedoče o intenzitetu proživljene traume. Ponekad je traumatična emocija toliko snažna da izmiče verbalizaciji, kao u iskazu Maksima Dimića. U trajne efekte preživljene traume valja ubrojiti i nastojanje pojedinih svjedoka poput Steve Brakusa 
i Branka Cetine da se za vrijeme svjedočanstva referiraju na vlastitu strepnju zbog trenutne političke situacije. Nekadašnji strah žrtava etničkih zločina tako se transformira u strepnju zbog etničkih tenzija koje su se u SFRJ događale u vrijeme kada su njihova svjedočanstva zabilježena. Zanimljivo je da, usprkos detaljnim i često intenzivnim opisima straha i bespomoćnosti povezanih s vlastitim stradanjem, nitko od preživjelih ne izražava želju za osvetom. Naravno, mnogi svjedoci govore kako ih je traumatično iskustvo učinilo osjetljivima za etničke podjele, no manifestacije takvog razmišljanja vide se tek u trenucima nakon što su žrtve izbjegle sigurnoj smrti. U nekim svjedočanstvima izražena je želja za pravdom, ali koncepcija pravde o kojoj žrtve govore više se odnosi na dostojanstveno odavanje počasti ubijenima ili na bolji socijalni tretman preživjelih (kao u slučaju Sofije Uzelac koja smatra da bi trebala dobiti pomoć od države) nego na njen retributivni aspekt. Takvo otkriće zasigurno baca zanimljivo svjetlo na kasniju retoriku u kojoj su brojni hrvatski i srpski nacionalisti koristili emocije vezane uz stradanja u Drugom svjetskom ratu za legitimaciju vlastitih političkih programa. Upravo analize emocija u svjedočanstvima osoba koje su preživjele strahote postaju snažno oruđe za demaskiranje pojedinih narativa prisutnih na političkoj sceni u kojima se glas žrtava aproprira u svrhu zagovaranja kolektivne osvete.

\section{LITERATURA}

American Psychiatric Association. 2013. Diagnostic and Statistic Manual of Mental Disorders, Fifth Edition (DSM-5). American Psychiatric Publishing. Arlington.

Arbanas, Ivan. 1989. Perušićki kotar u prvim danima okupacije i ustanka 1941. godine, u: Zatezalo, Đ. (ur.): Kotar Gospić i kotar Perušić u narodnooslobodilačkom ratu 1941-1945. Historijski arhiv u Karlovcu. Karlovac: 147-158.

Bergholz, Max. 2016. Violence as a Generative Force: Identity, Nationalism, and Memory in a Balkan Community. Cornell University Press. London.

Bourke, Joanna. 2003. Fear and Anxiety: Writing about Emotion in Modern History. History Workshop Journal, (55): 111-133.

Bourke, Joanna. 2006. Fear: A Cultural History. Shoemaker \& Hoard. Emeryville.

Cvetković, Dragan. 2010. Stradanje stanovništva NDH u logorima - numeričko određenje, u: Geiger, V., Grahek Ravančić, M. i Karakaš Obradov, M. (ur.): Logori, zatvori i prisilni rad u Hrvatskoj/Jugoslaviji 1941.-1945./1945.-1951. Hrvatski institut za povijest. Zagreb: 41-56.

Damasio, Antonio. 1999. The Feeling of What Happens: Body and Emotion in the Making of the Consciousness. Harcourt Brace \& Company. New York. 
Delimo, Žan. 2003. Strah na Zapadu: (od XIV do XVIII veka): opsednuti grad. Izdavačka knjižarnica Zorana Konstantinovića. Sremski Karlovci; Novi Sad.

Dizdar, Zdravko. 2017. Logor Danica u Koprivnici 1941. - 1942. Muzej grada Koprivnice. Koprivnica.

Geiger, Vladimir et al. 2017. Jadovno i Šaranova jama. Kontroverze i manipulacije. Hrvatski institut za povijest. Zagreb.

Goldstein, Ivo. 2001. Holokaust u Zagrebu. Novi Liber. Zagreb.

Goldstein, Slavko. 2007. 1941 - godina koja se vraća. Novi Liber. Zagreb.

Greenspan, Henry; Horowitz, Sara R.; Kovács, Éva; Lang, Berel; Laub, Dori; Waltzer, Kenneth; Wieviorka, Annette. 2014. Engaging Survivors: Assessing 'Testimony' and 'Trauma' as Foundational Concepts. Dapim: Studies on the Holocaust, (28), 3: 190-226.

Hrvatski glas. 1941. Broj 83.

Jelić-Butić, Fikreta. 1977. Ustaše i Nezavisna Država Hrvatska 1941-1945. SN Liber, Školska Knjiga. Zagreb.

Krizman, Bogdan. 1978. Pavelić i ustaše. Globus. Zagreb.

Laub, Dori. 2002. Testimonies in the Treatment of Genocidal Trauma. Journal of Applied Psychoanalytic Studies, (4), 1: 63-87.

Matković, Hrvoje. 2002. Povijest Nezavisne Države Hrvatske. Naklada P.I.P. Pavičić. Zagreb.

Mrkalj, Igor. 2018. Slovenac među Hrvatima i Srbima: Franc Žužek, župnik u Glini, 1927. - 1955. Tragovi, (1), 1: 124-165.

NDH. 1941. Zakoni, zakonske odredbe i naredbe proglašene od 11. travnja do 26. svibnja 1941. Zagreb.

Opačić, Dušan. 1988. Pokolj Srba u Hrvatskom Blagaju, maja 1941. godine, u: Zatezalo, Đ. (ur.): Kotar Slunj i kotar Veljun u NOR-u i socijalističkoj izgradnji. Historijski arhiv u Karlovcu. Karlovac: 140-153.

Peršen, Mirko. 1966. Ustaški logori. Stvarnost. Zagreb.

Plamper, Jan. 2015. The History of emotions: An Introduction. Oxford University Press. Oxford.

Rajčević, Dane. 1989. Zločini ustaša nad stanovnicima Divosela, Čitluka i Ornica u prvoj polovini augusta 1941. godine, u: Zatezalo, Đ. (ur.): Kotar Gospić i kotar Perušić u narodnooslobodilačkom ratu 1941-1945. Historijski arhiv u Karlovcu. Karlovac: 209-230.

Reddy, William M. 2001. The Navigation of Feeling: A Framework for the History of Emotions. Cambridge University Press. New York.

Rushdie, Asraf H. A. 1990. "Rememory": Primal Scenes and Constructions in Toni Morrison's Novels. Contemporary Literature, (31), 3: 300-323. 
Stearns, Peter. 2003. Anxious Parents: A History of Modern Childrearing in America. New York University Press. New York, London.

Škiljan, Filip. 2012. Organizirano masovno prisilno iseljavanje Srba iz Hrvatske 1941. godine. Stanovništvo, 2: 1-34.

Škiljan, Filip. 2014. Organizirana prisilna iseljavanja Srba iz NDH. Srpsko narodno vijeće. Zagreb.

Tomasevich, Jozo. 2001. War and Revolution in Yugoslavia 1941-1945: Occupation and Collaboration. Stanford University Press. Stanford, California.

Uzelac, Grga. 1963. Smiljan u 1941. godini, u: Jovanić, Đ. (ur.): Lika u NOB 1941. Vojno delo. Beograd: 483-493.

Zatezalo, Đuro. 2005. Radio sam svoj seljački i kovački posao. Srpsko kulturno društvo "Prosvjeta". Zagreb.

Zatezalo, Đuro. 2007. Jadovno - kompleks ustaških logora 1941. Muzej žrtava genocida. Beograd.

Zdunić Lav, Franjo. 1989. Ustaški zločini na Jadovnom i u nekim drugim logorima smrti uz osvrt na njihove korijene, u: Zatezalo, Đ. (ur.): Kotar Gospić i kotar Perušić u narodnooslobodilačkom ratu 1941-1945. Historijski arhiv u Karlovcu. Karlovac: 168-200.

Zemljar, Ante. 1988. Haron i sudbine. Četvrti jul. Beograd.

Igor Drvendžija, Vinko Drača

THE ANALYSIS OF EMOTIONS IN SURVIVORS' TESTIMONIES ON SUMMER OF 1941 IN CONCENTRATION CAMPS

GOSPIĆ-JADOVNO-PAG

\begin{abstract}
Summary
In this paper the authors analyze the emotions of survivors of the camp system Gospić-Jadovno-Pag, where people of Serb and Jewish ethnic descent were murdered during the summer of 1941, as well as communists and other political enemies of the ustashi regime. The approach to the study of emotions is based on the eyewitness accounts published by the historian Đuro Zatezalo. The paper starts with an analysis of the emotions in history with a particular emphasis on the testimonies of survivors as a distinctive and extremely important source in the studies of the Holocaust and genocide. Afterwards, the authors examine the intentions of those who collected the testimonies, as well as memories and emotions as aspects which a historian who researches testimonies ought to have in mind. A description of the impact of race laws issued by the Independent State of Croatia is provided together with an overview of
\end{abstract}


the history of the camp system Gospić-Jadovno-Pag, followed by an analysis of the emotives expressed in the testimonies, with the focus on the emotions of fear, anxiety, hope and joy. The relation between recollection and emotions is also discussed, in addition to the way in which the flow of time can alter the intensity and the contents of emotion, which can provide a valuable methodological insight to the researchers focusing on the history of genocide and oral history.

Keywords: Independent State of Croatia, Jadovno, Civilian Casualties of Second World War, Emotions, Testimonies

Igor Drvendžija je doktorand na Odsjeku za povijest Filozofskog fakulteta Sveučilišta u Zagrebu.

Vinko Drača je doktorand na Odsjeku za povijest Filozofskog fakulteta Sveučilišta u Zagrebu.

Kontakti:

Igor Drvendžija, Arhiv Srba u Hrvatskoj, Mažuranićev trg 6, 10000 Zagreb. E-mail: igor.drvendzija@snv.hr

Vinko Drača, Filozofski fakultet, Odsjek za povijest, Ive Lučića 3, 10000 Zagreb. E-mail: vinko.draca@gmail.com 